\title{
Detection of Platelet-derived Growth Factor (PDGF)-AA in Actively Healing Human Wounds Treated with Recombinant PDGF-BB and Absence of PDGF in Chronic Nonhealing Wounds
}

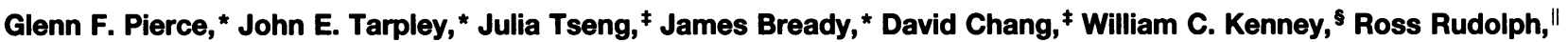 \\ Martin C. Robson, $\uparrow$ Jerny Vande Berg, ${ }^{\star \star}$ Patricia Reid, ${ }^{\star \star}$ Stephen Kaufman, ${ }^{\star}$ and Catherine L. Farrell \\ Departments of $*$ Experimental Pathology, ${ }^{\ddagger}$ Immunology, and ${ }^{\S}$ Protein Chemistry, Amgen Inc., Thousand Oaks, California 91320 ; \\ "Division of Plastic Surgery, Scripps Clinic and Research Foundation and the University of California, San Diego, La Jolla, California \\ 92037; 'Department of Surgery, University of South Florida, Tampa, Florida 33504; and **Core Electron Microscopy Lab, Veteran's \\ Administration Medical Center, University of California, San Diego, La Jolla, California 92161
}

\begin{abstract}
Some human chronic dermal wounds treated with recombinant platelet-derived growth factor-BB (rPDGF-BB) show increased healing coupled with fibroblast activation and granulation tissue formation. To determine whether endogenous PDGF is associated with healing and nonhealing dermal ulcer phenotypes, we developed monoclonal antibodies capable of recognizing the three isoforms of PDGF, AA, AB, and $B B$ dimers, and capable of discriminating between two alternatively spliced A chain transcripts. We detected little PDGF isoform expression in normal skin and in nonhealing dermal ulcers. In contrast, in surgically created acute wounds and chronic ulcers treated with rPDGF-BB, markedly upregulated levels of PDGF-AA (long form) were found. In both types of wounds, increased PDGF-AA was detected primarily in capillaries and fibroblasts, although in rPDGF-BB-treated chronic wounds, widespread expression of PDGF-AA was somewhat delayed. With continued treatment, the long form of PDGF-AA, which can preferentially bind extracellular matrix, was expressed only in capillaries, while fibroblasts began synthesizing the short form of PDGF-AA. Within capillaries, all endothelial cells and varying numbers of pericytes and smooth muscle cells contained PDGF-AA. In all wounds, macrophages and keratinocytes were not a major contributor. While PDGF-BB and PDGF-AB were present in a minority of healing wounds, they were usually present at lower levels than PDGF-AA. PDGF- $\beta$ receptors, which bind only PDGF-BB and not other isoforms, were found in normal skin and granulation tissue, providing a molecular basis for treating human chronic wounds with exogenous rPDGF-BB. (J. Clin. Invest. 1995. 96:1336-1350.) Key words: skin • dermis • immunohistochemistry • monoclonal antibodies

\section{Introduction}

The molecular mechanisms responsible for healing wounds remain a mystery. In experimental tissue repair models, epithelial

Address correspondence to Glenn F. Pierce, Ph.D., M.D., Dept. of Preclinical Development, Prizm Pharmaceuticals, 11035 Roselle St., San Diego, CA 92121. Phone: 619-625-0100; FAX: 619-625-0222. Address reprint requests to Catherine Farrell, Ph.D., Dept. of Experimental Pathology, 15-2-A-226, Amgen Inc., Thousand Oaks, CA 91320-1789. Received for publication 29 July 1994 and accepted in revised form 22 May 1995.

The Journal of Clinical Investigation, Inc.

Volume 96, September 1995, 1336-1350 cells, endothelial cells, and fibroblasts clearly are required (13 ). When activated, these cell types initiate repair processes necessary for normal repair, i.e., reepithelialization, angiogenesis, and extracellular matrix deposition (4-6). In addition, wound macrophages, but not wound neutrophils, are necessary for normal repair (7). These diverse cell types migrate, proliferate, and differentiate, eventually producing a collagen-containing scar. Specific growth factors are believed to regulate these processes because cell types found within wounds both synthesize and bear receptors for a variety of growth factors in vitro (8-17), and growth factors pharmacologically applied to wounds can accelerate in vivo repair $(2,3,5,6,10,18-23)$. Growth factors have also been implicated in the pathogenesis of lesions of the vascular wall and in tumor growth, consistent with the notion that these pathophysiologic processes share commonalities with normal tissue repair processes (24-26). Recently, neutralizing antibodies to basic fibroblast growth factor have been shown to decrease granulation tissue formation within sponges implanted subcutaneously in rodents, providing direct evidence for the role of a growth factor in tissue repair (27). However, formal proof that endogenous growth factors mediate normal wound healing is lacking, due at least in part to a lack of specific analytical reagents.

Platelet-derived growth factor (PDGF) was originally identified by Ross et al. (28) and Kohler and Lipton (29) as the most potent mitogen in serum for mesenchymally derived cells. Purified human platelet PDGF is predominantly a heterodimeric molecule consisting of $A$ and $B$ chains, which are $\sim 60 \%$ homologous at the amino acid level $(3,17)$. The B chain is highly homologous $(\sim 92 \%)$ to $\mathrm{v}-$ sis, the oncogene of Simian sarcoma virus, an acutely transforming retrovirus (3). Both BB and AA homodimers have been isolated from natural sources $(3,17)$. A number of cell types contain message for A chain and/or B chain, including macrophages, endothelial cells, smooth and skeletal muscle cells, and fibroblasts. These cells secrete PDGFlike proteins; however, identification of the specific isoform(s) secreted has been often hampered by the lack of reagents to specifically detect each isoform. In addition, multiple transcripts have been detected in cells which produce PDGF-AA $(30,31)$. They appear to be alternative splice variants of a single sevenexon gene, and give rise to short $(\mathrm{S})$ and long $(\mathrm{L})$ processed proteins of $110\left(A_{S}\right)^{1}$ and $125\left(A_{L}\right)$ amino acids $(30-32)$. The shorter transcript is lacking exon VI, which contains 69 base pairs. Differences in regulation of the transcripts but not in

1. Abbreviations used in this paper: $\mathrm{CHO}$, Chinese hamster ovary; PDGF-AA $A_{L}$ and $-\mathrm{AA}_{S}$, the long and short forms of AA homodimers of PDGF. 
Table I. Characterization of the Specificity of Anti-PDGF Monoclonal Antibodies for PDGF Isoforms

\begin{tabular}{|c|c|c|c|c|c|c|c|c|c|c|c|c|c|c|c|c|}
\hline \multirow{3}{*}{$\begin{array}{l}\text { IgG subtype } \\
\text { PDGF isoform }\end{array}$} & \multicolumn{4}{|c|}{$6 C-51$} & \multicolumn{4}{|c|}{$3 \mathrm{E}-205$} & \multicolumn{4}{|c|}{$4 E-4$} & \multicolumn{4}{|c|}{$1 F-133$} \\
\hline & \multicolumn{4}{|c|}{1} & \multicolumn{4}{|c|}{$2 b$} & \multicolumn{4}{|c|}{1} & \multicolumn{4}{|c|}{$2 a$} \\
\hline & $\mathrm{AA}_{\mathrm{L}}$ & $\mathrm{AA}_{\mathrm{s}}$ & $\mathrm{AB}$ & BB & $\mathrm{AA}_{\mathrm{L}}$ & $\mathbf{A A}_{\mathbf{s}}$ & $\mathrm{AB}$ & BB & $\mathrm{AA}_{\mathbf{L}}$ & $\mathbf{A A}_{\mathbf{s}}$ & $\mathrm{AB}$ & BB & $\mathbf{A A}_{\mathbf{L}}$ & $\mathrm{AA}_{\mathbf{s}}$ & $\mathrm{AB}$ & BB \\
\hline RIA & + & - & + & - & + & + & - & - & - & NT & - & $+^{*}$ & - & NT & + & $+*$ \\
\hline Nitrocellulose blot & + & - & + & - & + & + & - & - & - & - & - & + & - & - & + & + \\
\hline Western blot & + & NT & + & - & + & NT & - & - & - & - & - & + & - & NT & + & + \\
\hline $\mathrm{CHO}$ cells $^{\ddagger}$ & + & NT & NT & - & + & NT & NT & - & - & NT & NT & + & - & NT & NT & + \\
\hline BIAcore & + & NT & + & - & + & NT & - & - & - & NT & - & + & - & NT & + & + \\
\hline Antibody specificity & \multicolumn{4}{|c|}{$\mathrm{AA}_{\mathrm{L}} / \mathrm{AB}$} & \multicolumn{4}{|c|}{$\mathbf{A A}_{\mathbf{S}} / \mathbf{A A}_{\mathbf{L}}$} & \multicolumn{4}{|c|}{ BB } & \multicolumn{4}{|c|}{$\mathrm{BB} / \mathrm{AB}$} \\
\hline
\end{tabular}

${ }^{\ddagger}$ Two CHO lines were used, expressing PDGF-AA $\mathrm{L}_{\mathrm{L}}$ or $-\mathrm{BB} .{ }^{*}$ These antibodies react with both PDGF-BB 109 or 119 amino acids in length. NT, not tested.

bioactivity of the protein products have been reported $(16,33)$. Transcripts for both proteins have been detected in multiple cell types, however, $\mathrm{AA}_{\mathrm{S}}$ is thought to be produced to a greater extent than $\mathrm{AA}_{\mathrm{L}}$ (34).

All three isoforms, $\mathrm{BB}, \mathrm{AB}$, and $\mathrm{AA}$, may bind to PDGF $\alpha$ receptors; however, only the $\mathrm{BB}$ isoform is capable of binding to PDGF- $\beta$ receptors (35-37). Both receptors are highly homologous tyrosine kinases and are present on specific cell types, providing for target cell specificity of the PDGF response (38). In addition, some cells may display both receptors. Thus, although the actual physiological functions of PDGF remain unknown, its actions are regulated by the need for specific ligandreceptor interactions to transduce stimulating signals.

In this report, using newly developed specific and sensitive serological reagents which recognize each PDGF isoform, we demonstrate the marked upregulation of predominantly PDGFAA within healing pressure ulcers. This remarkable accumulation of PDGF-AA is accompanied by activated fibroblasts, extracellular matrix deposition, and active neovessel formation. In contrast, little PDGF was observed in chronic nonhealing wounds, confirming the potential benefit of applying recombinant PDGF-BB to wounds (39-41). Collectively, these results suggest an important role for PDGF isoforms in the normal repair process.

\begin{tabular}{|l|c|c|c|c|}
\hline Antibody & $A A_{L} / A B$ & $A_{S} / A_{L}$ & $B B$ & $B B / A B$ \\
\hline Clone & $(6 C-51)$ & $(3 E-205)$ & $(4 E-4)$ & $(1 F-133)$ \\
\hline $\begin{array}{l}\text { No Antigen } \\
\text { PDGF-AAL }\end{array}$ & - & - & & \\
PDGF-AB & - & & & - \\
PDGF-BB & & & - & - \\
\hline
\end{tabular}

Figure 1. Immunoreactivity of anti-PDGF monoclonal antibodies toward PDGF isoforms using a solid-phase nitrocellulose-based assay. Excess antigen $\left(A A_{L}, A B\right.$, or $B B$ ) was used to titer out each antibody in order to assess specificity at limiting antibody concentrations (see Methods). At very high antibody concentrations, full cross-reactivity between PDGF isoforms was observed.

\section{Methods}

\section{Human tissues}

Tissue biopsies were obtained from pressure ulcer patients participating in clinical trials using recombinant PDGF-BB. Patients from the first trial were young adults with spinal cord injuries and chronic nonhealing pressure ulcers. Patients in this trial were aggressively surgically debrided at the beginning of the treatment period, therefore, their ulcers represent more acute wounds and all ulcers demonstrated marked healing during the trial (39). Biopsies were obtained from patients receiving either $100 \mu \mathrm{g} / \mathrm{ml}\left(1 \mu \mathrm{g} / \mathrm{cm}^{2}\right)$ recombinant (r) PDGF-BB or placebo daily for $28 \mathrm{~d}$ (39). Patients from the second trial were elderly adults with chronic, nonhealing ulcers (40). Patients from this trial received only minor, blunt debridement, thus their ulcers represent chronic, nonhealing wounds. Patients in this trial received either 100 or $300 \mu \mathrm{g} / \mathrm{ml}$

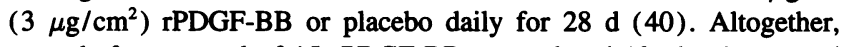
wounds from a total of 15 rPDGF-BB-treated and 13 placebo-treated patients were analyzed. Both trials were approved by their respective Institutional Review Boards.

\section{Tissue handling and preparation}

At multiple time points each patient was biopsied using a 3-mm biopsy punch, and tissues not destined for electron microscopy were placed in OmniFix II (An-Con Genetics, Melville, NY). Tissues used for electron microscopy were collected into a modified McDowell-Trump fixative ( $0.5 \%$ glutaraldehyde and $1.5 \%$ paraformaldehyde in $0.1 \mathrm{M}$ phosphate buffer, $\mathrm{pH}$ 7.4) for $24 \mathrm{~h}$. Biopsies were placed in fresh fixative, minced into $0.5-\mathrm{mm}^{3}$ pieces, and stored at $4^{\circ} \mathrm{C}$ in fixative before processing. Samples were dehydrated, post-fixed with uranyl acetate, and embedded in LR White Resin (medium grade; Ted Pella, Inc., Redding, CA). The receptor antibodies required unfixed, frozen tissues, so unfixed skin samples were obtained from other sources. Normal skin was obtained from a patient undergoing abdominal surgery and granulation tissue was obtained from a patient undergoing rhinoplasty. These were shipped in Zeus solution (Zeus Scientific Inc., Raritan, NJ), snap-frozen in OCT (Miles, Inc., Elkhart, IN), and stored at $-80^{\circ} \mathrm{C}$.

\section{Generation of PDGF monoclonal antibodies}

Recombinant PDGF isoforms. Recombinant PDGF-BB and AA isoforms were produced in Escherichia coli using the full-length cDNA (119 amino acids for the B monomer and 125 amino acids for the A monomer). Homodimers were created during purification and refolding and contained no detectable monomer. Heterodimeric PDGF-AB was generated by combining the inclusion bodies from two $E$. coli lines transfected with either PDGF-A or PDGF-B cDNAs. During purification using metal ion chromatography, homodimeric species were separated from the heterodimer and were not detectable in purified heterodimer preparations. A shorter form of PDGF-AA; 109 amino acids in length 

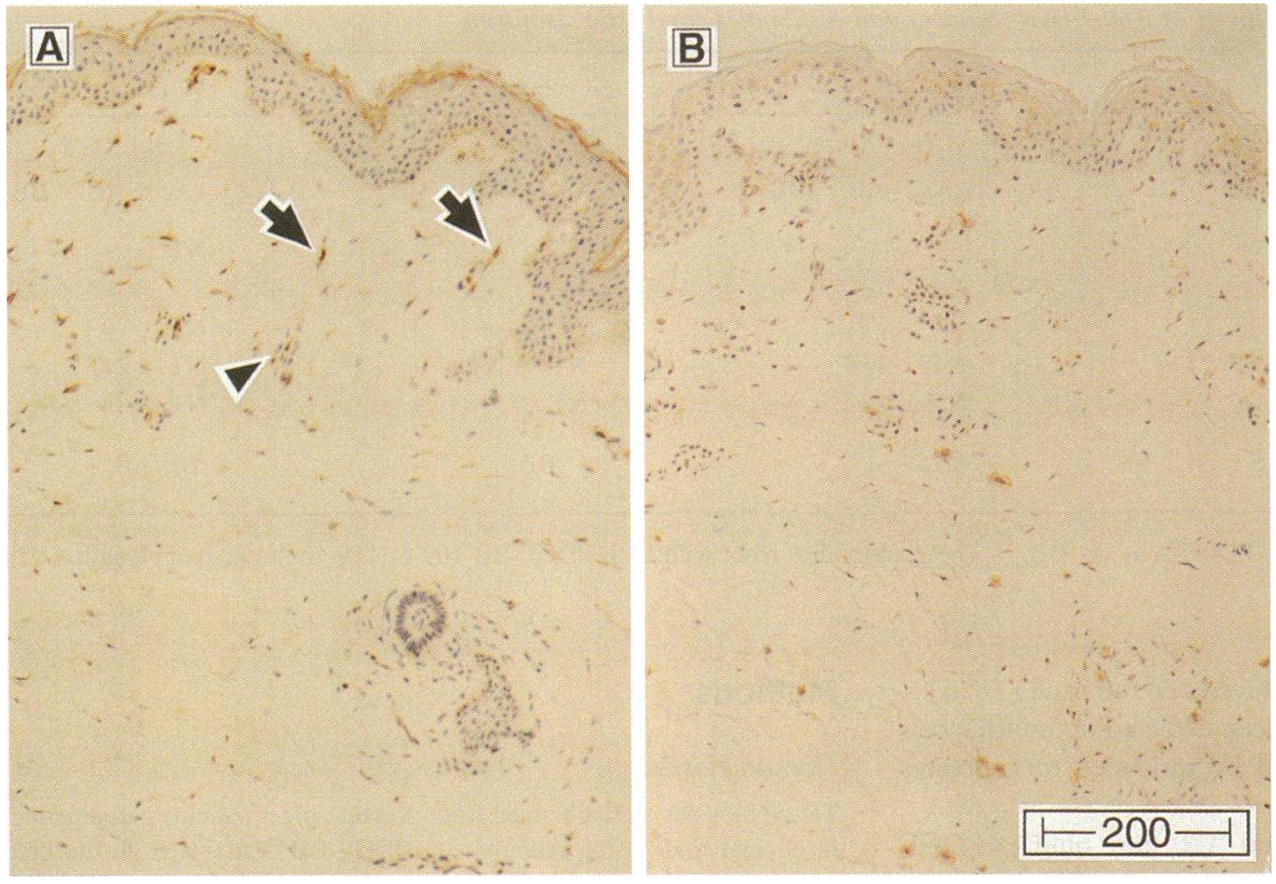

Figure 2. Identification and localization of PDGF isoforms in normal human skin. (A) PDGF-AA (6C-51) was detected in dermal fibroblasts (arrows) and capillaries (arrowhead). (B) Little PDGF-BB/AB (1F-133) was found. The strongly stained cells are mast cells, which bind the chromagen. Original magnification, $\times 80$.

$\left(\mathrm{AA}_{\mathrm{S}}\right)$, was produced in Chinese hamster ovary $(\mathrm{CHO})$ cells and was used in some experiments to assess antibody specificity.

Antibody production and purification. Antibodies were produced by standard monoclonal antibody production methods. Briefly, mice were immunized with three injections of rPDGF-BB (119 amino acids) in Ribi adjuvant (Ribi ImmunoChem Research, Inc., Hamilton, MT) or rPDGF-AA ( $\mathrm{AA}_{\mathrm{L}}, 125$ amino acids) in Freund's complete adjuvant (Difco Laboratories, Detroit, MI). Hybridomas were screened by enzyme immunoassay and positive wells were cloned by limiting dilution. 24 clones from PDGF-AA immunization and 14 clones from PDGFBB immunization were tested by immunohistochemistry using transfected $\mathrm{CHO}$ cell lines (see below). Based upon screening assays, two anti-PDGF-AA clones, 6C-51 and 3E-205, and two anti-PDGF-
BB clones, 4E-4 and 1F-133, were chosen for this study. None of the antibodies were capable of neutralizing PDGF activity.

Antibodies were purified using protein A chromatography (AvidChrom Ab kit; Unisyn Technology, Tustin, CA), diluted 1:10 in 1\% bovine serum albumin in Dulbecco's phosphate-buffered saline (PBS) (Sigma Immunochemicals, St. Louis, MO) plus 0.03\% Brij-35 (Fisher Scientific, Fair Lawn, NJ) and $0.01 \%$ thimerosal (Sigma Immunochemicals), and were aliquoted and stored at $-80^{\circ} \mathrm{C}$.

\section{Characterization of antibody specificity}

Transfected $\mathrm{CHO}$ cell controls. Positive control paraffin blocks were prepared using $\mathrm{CHO}$ cells transfected with the PDGF- $\mathrm{A}_{\mathrm{L}}$ gene (CHO$\mathrm{AA}$ ) or the PDGF-B gene (CHO-BB). Both cell lines were made from

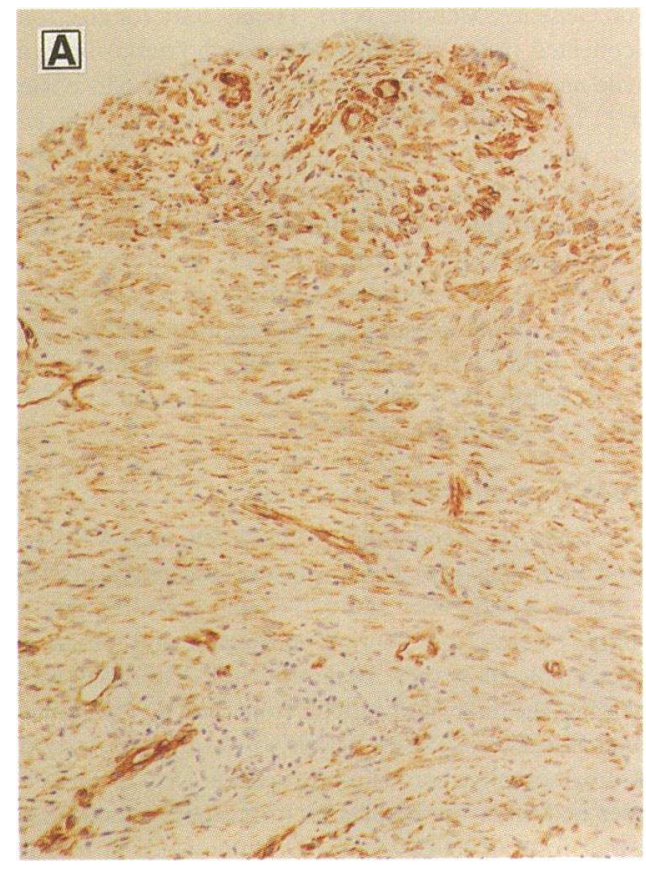

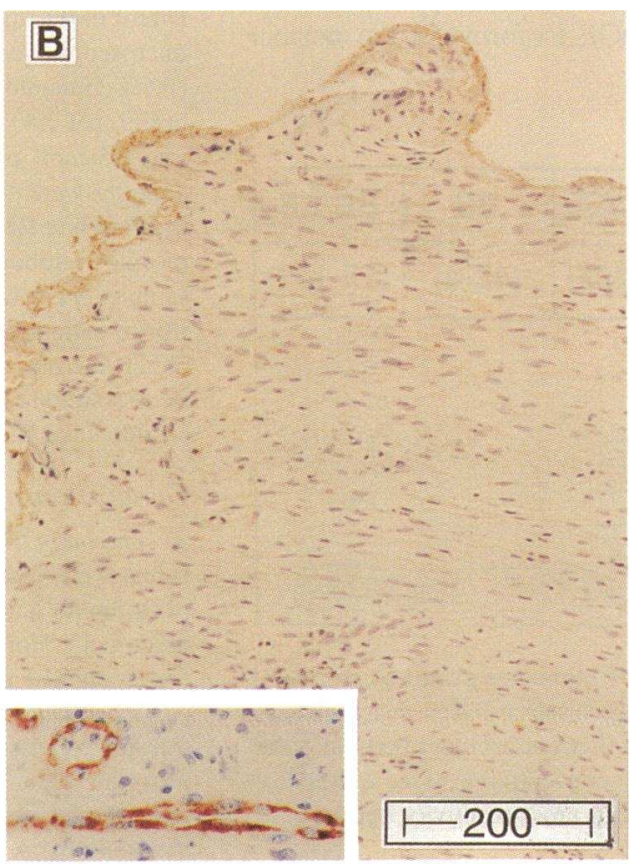

Figure 3. Identification and localization of PDGF isoforms in active granulation tissue from surgical wounds. (A) PDGF-AA $\mathrm{L}$ (6C-51) intensely stained fibroblasts and capillaries. $(B)$ No PDGF-BB/AB (1F-133) or -AA $A_{S}$ (3E-205, data not shown) was detected. Original magnification, $\times 80$. Inset, von Willebrand factor staining of endothelial cells within a vessel. Original magnification, $\times 100$. 

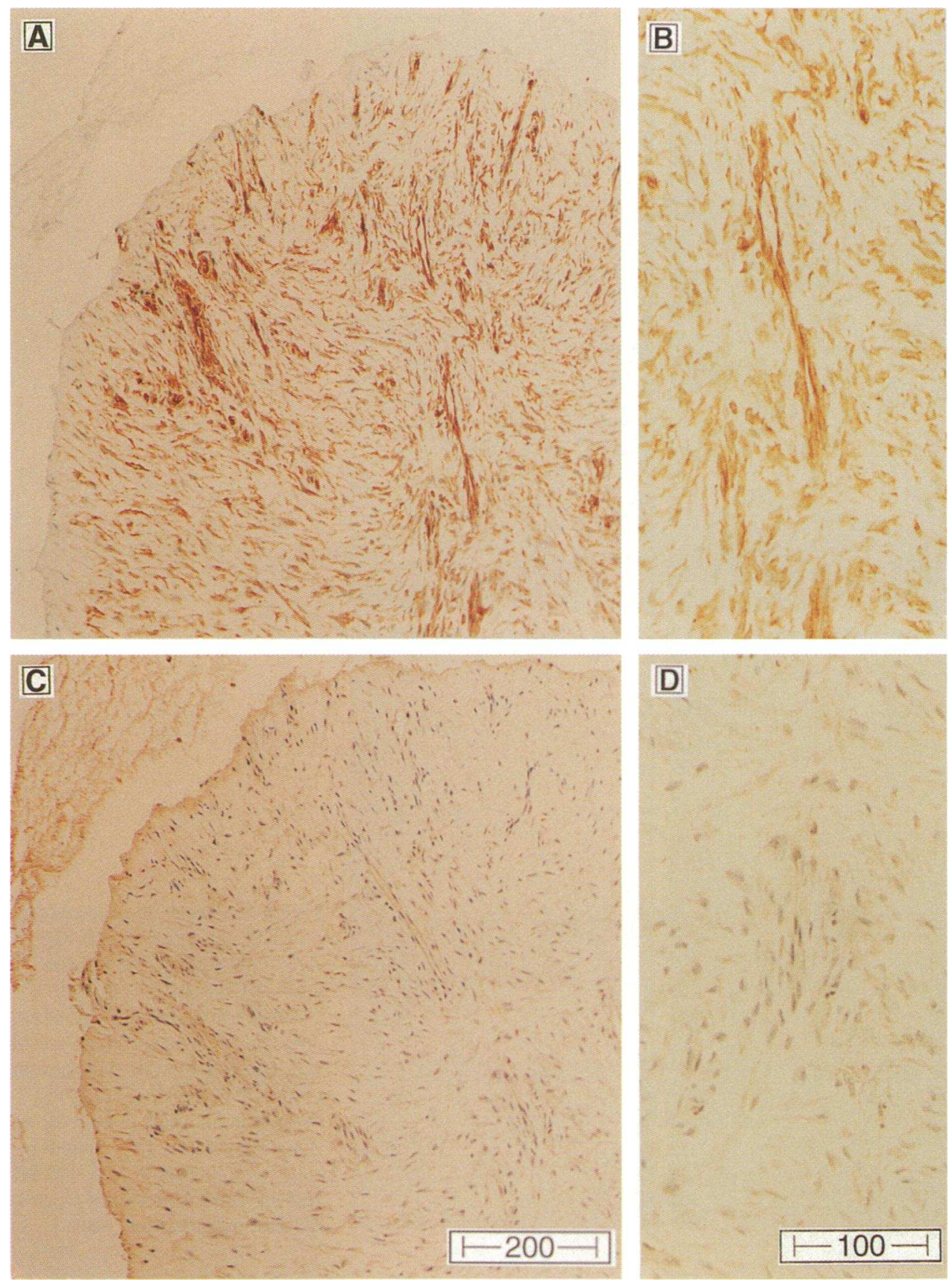

Figure 4. Identification of PDGF isoforms in actively healing pressure ulcers. Surgically created acute wounds were created by sharp debridement of pressure ulcers to healthy tissue margins (39). ( $A$ and $B$ ) PDGF-AA $A_{L}(6 C-51)$ was the predominant isoform expressed, although $(C$ and $D)$ some PDGF-AB and -BB (1F-133) expression was detected in fibroblasts and capillaries. Original magnification in $A$ and $C, \times 80$; original magnification in $B$ and $D, \times 160$.

full-length transcripts which included the pre-pro and post regions of the gene. The nontransfected parental cell line $\left(\mathrm{CHO}^{-} \mathrm{D}^{-}\right)$was used as a negative control. Cells from each line were grown in standard tissue culture flasks, trypsinized, and pelleted. The pellets were resuspended in a small volume of media and dripped onto the surface of a collagen sponge disk (CollaPlug; Colla-Tec, Inc., Plainsboro, NJ). The sponge with entrapped cells was processed and sectioned for light microscopy as described above.

Western blots. Purified recombinant PDGF-AA, PDGF-AB, and PDGF-BB were loaded on 16\% Tris-glycine gels under nonreducing conditions. After SDS-gel electrophoresis (Xcell Mini-Cell; Novex, San Diego, CA) the gels were transferred to nitrocellulose and probed with each antibody. Blots were then reacted with a biotinylated horse antimouse secondary antibody (Vector Laboratories, Burlingame, CA) followed by avidin-biotin complex (ABC Elite kit; Vector Laboratories) and developed with 4-chloro-1-naphthol/hydrogen peroxide (GIBCO BRL, Gaithersburg, MD).

Nitrocellulose-based immunoassay. A membrane solid phase immunoassay was done to determine the sensitivity of each antibody for the immunizing homodimer as well as to assess cross-reactivity with the other homodimer and the heterodimer, using nitrocellulose in a Minifold II (reference 42; Schleicher \& Schuell, Inc., Keene, NH). Each antibody was tested against $100 \mathrm{ng} / \mathrm{ml}$ of each dimer. Antibodies were titrated over a wide dilution range, from $100 \mathrm{ng} / \mathrm{ml}$ to $100 \mu \mathrm{g} / \mathrm{ml}$. Reactions were carried out as described above for Western blots.

BIAcore assay. Real-time biospecific interaction analysis based on surface plasmon resonance was conducted using a BIAcore instrument (Pharmacia Biosensor, Uppsala, Sweden). Surface plasmon resonance detects changes in optical properties at the surface of a sensor chip. The sensor chips (CM5; Pharmacia Biosensor) consist of a glass support for a thin gold film which carries a dextran matrix for coupling samples. This is attached to a micro flow cell through which reactants are passed. Antibody-antigen binding is measured by an increase in resonance units. Optical measurement of resonance units results from a change of 

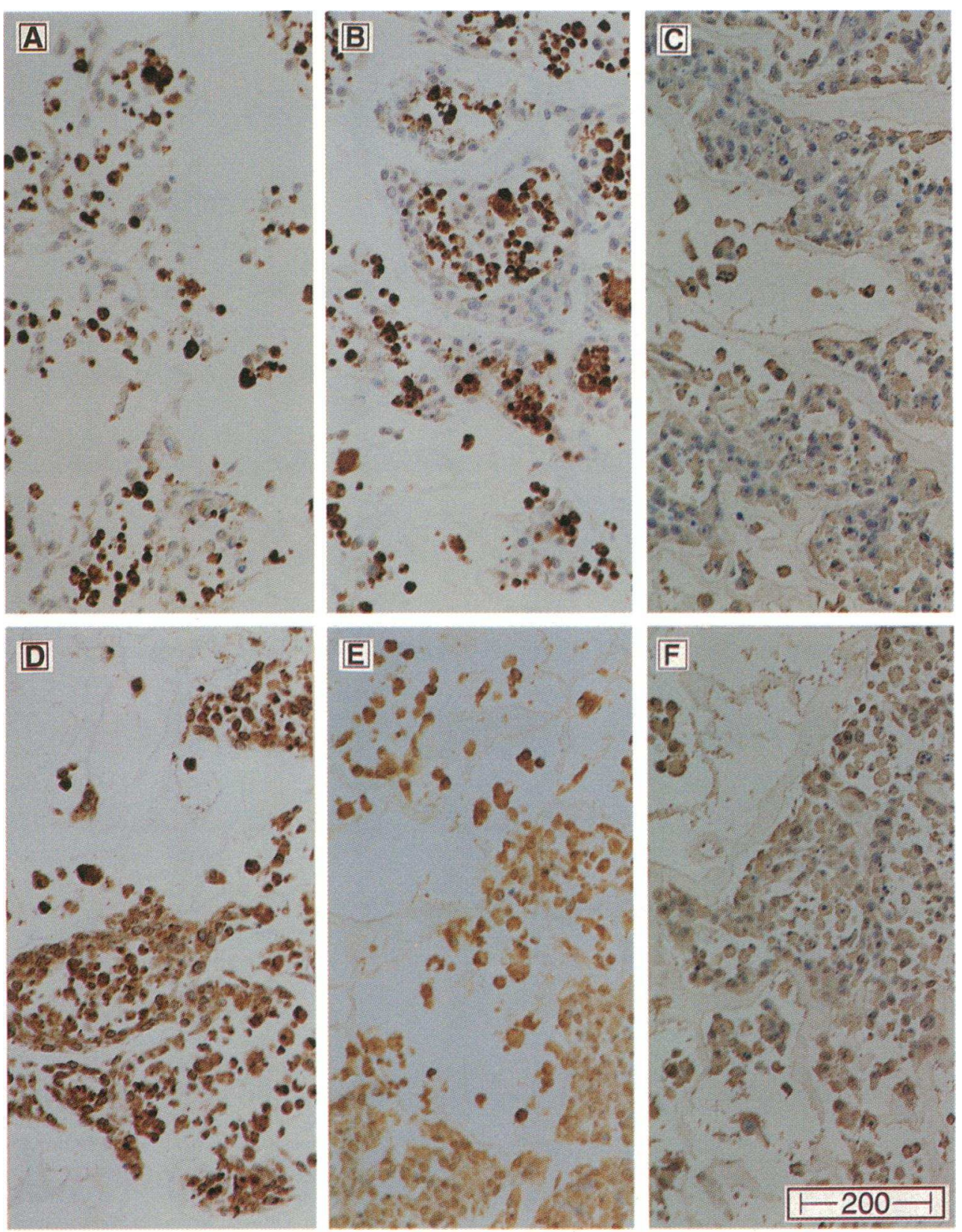

Figure 5. Competition experiments on $\mathrm{CHO}$ cells expressing PDGF$\mathrm{AA}_{\mathrm{L}}$. (A) Normal staining with anti-PDGF-AA $A_{L} / \mathrm{AB}(6 \mathrm{C}-51)$. Staining is not diminished by excess $\mathrm{AA}_{\mathbf{s}}(B)$ but is competed by excess $\mathrm{AA}_{\mathrm{L}}(C)$. (D) Normal staining with anti-PDGF-AA $A_{L} / A_{A}(3 E-205)$.

Staining is competed by both excess $\mathrm{AA}_{\mathrm{S}}(E)$ and $\mathrm{AA}_{\mathrm{L}}(F)$. Similar results were obtained for the anti-BB reagents using their specific ligands. Original magnification, $\times 80$.

resonance angle at a stationary sensor which depends on the refractive index in the vicinity of the surface that changes as the concentration (binding) of molecules on the surface is changed $(43,44)$. Each form of PDGF ( $A A_{L}, B B$, and $A B$ ) was covalently coupled to a separate sensor chip using an amine coupling kit (Pharmacia Biosensor). Antibody pairs were tested for binding with each PDGF isoform by injecting the first antibody of each pair, allowing an opportunity for binding, followed by injecting the second antibody and assessing the extent of its binding. The chips were then regenerated and the order of injections for each pair was reversed.

\section{Immunohistochemistry}

Immunohistochemistry was performed as described (6) using 3- $\mu \mathrm{m}$ sections cut on poly-L-lysine-coated ProbOn slides (Fisher Scientific, Pittsburgh, PA) and dried for $20 \mathrm{~min}$ at $60^{\circ} \mathrm{C}$. Briefly, the slides were quenched in $3 \%$ hydrogen peroxide, blocked with $10 \%$ normal horse serum, and stained with the primary antibody, a substitution control, or an irrelevant antibody (anti-GFAP of the same isotype as the primary; Boehringer Mannheim, Indianapolis, IN) for $1 \mathrm{~h}$ at room temperature.

Optimal concentrations were determined for each primary (6C-51, 1.2 $\mu \mathrm{g} / \mathrm{ml} ; 3 \mathrm{E}-205,100 \mu \mathrm{g} / \mathrm{ml} ; 4 \mathrm{E}-4,80 \mu \mathrm{g} / \mathrm{ml}$; and $1 \mathrm{~F}-133,158 \mu \mathrm{g} / \mathrm{ml})$. A biotinylated horse anti-mouse IgG secondary antibody, rat absorbed (Vector Laboratories), was applied for $\mathbf{3 0} \mathrm{min}$, followed by an avidinbiotin complex (ABC Elite kit; Vector Laboratories) for $30 \mathrm{~min}$. Diaminobenzidine (Sigma Immunochemicals) was used as the chromagen. To confirm antibody access to each tissue sample, duplicate sections were stained with anti-von Willebrand factor (1:400; Dako Corp., Carpinteria, CA). Endothelial cells lining vessels in each section were assessed for stain intensity.

For PDGF- $\beta$ receptor detection on specific cell types, identified by using a cell type-specific antibody, 5- $\mu \mathrm{m}$ frozen sections were stained on a Histostainer Ig (Leica Inc., Deerfield, IL) modifying a procedure (45) for localization of two antigens. Briefly, the slides were quenched in $1 \%$ hydrogen peroxide and stained with the first monoclonal antibody or a control matched IgG in $1 \%$ BSA-PBS, $0.05 \%$ Tween 20 , and $0.02 \%$ sodium azide for $1 \mathrm{~h}$ at room temperature. After rinsing, the slides were blocked in $20 \%$ normal goat serum in the same buffer and then incubated with $1 \mathrm{~nm}$ of immunogold-conjugated goat anti-mouse secondary anti- 

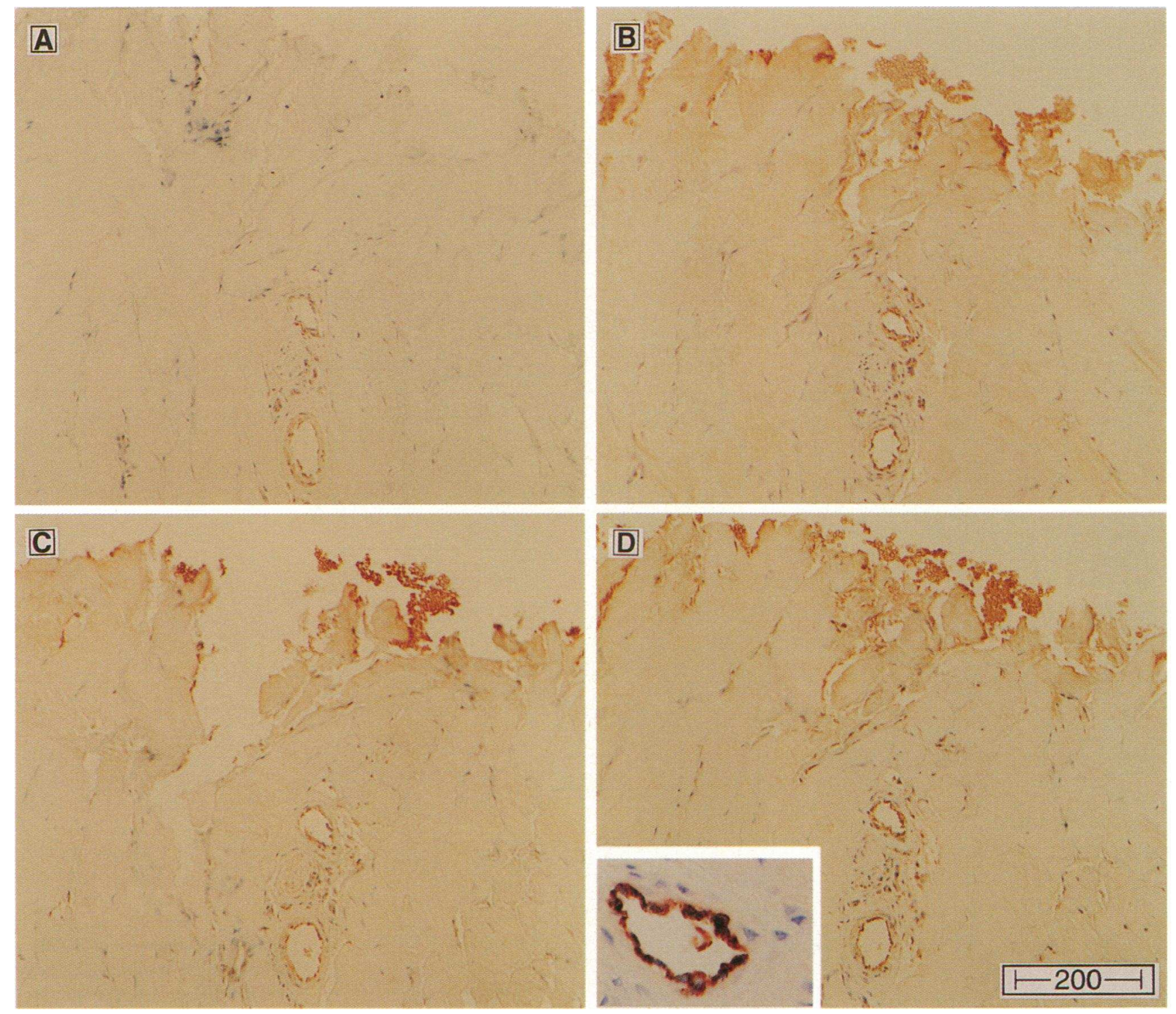

Figure 6. Identification of PDGF isoforms in chronic, nonhealing pressure ulcers. Chronic, noninfected wounds were characterized by sparse cellularity, little vasculature, and quiescent-appearing fibroblasts. (A) Anti-AA $\mathrm{L}_{\mathrm{L}} / \mathrm{AB}(6 \mathrm{C}-51) ;(B)$ anti-AA $/ \mathrm{AA}_{\mathrm{L}}(3 \mathrm{E}-205)$; $(C)$ anti-BB (4E-4); $(D)$ anti-AB/BB (1F-133). PDGF-BB is present, and some or all of the other isoforms are also present, but overall staining was markedly weaker than that observed in acute wounds. Inset, von Willebrand factor staining showing equal stain intensity as seen in acute healing wounds (Fig. 3, inset). Original magnification, $\times 80$.

body (Amersham International, Buckinghamshire, United Kingdom) diluted 1:40 in the same buffer. The staining was silver enhanced to give a black reaction product with the IntenSEM ${ }^{\mathrm{TM}}$ (Amersham International). Slides were rinsed overnight in PBS, endogenous avidin and biotin were blocked, and then slides were incubated with the second monoclonal or control matched IgG antibody for $1 \mathrm{~h}$ at room temperature. Slides were then incubated with biotinylated secondary antibody (Zymed Laboratories, Inc., South San Francisco, CA), diluted to $1.25 \mu \mathrm{g} / \mathrm{ml}$, and subsequently with avidin-peroxidase (Zymed Laboratories, Inc.) diluted 1:1,000. Sections were incubated using aminoethylcarbozide (Vector Laboratories) as a substrate to produce red staining with the second primary antibody. The slides were coverslipped with Aqua-Mount (Lerner Labs, Pittsburgh, PA).

Optimal concentrations of anti-PDGF- $\beta$ receptor and cell typespecific antibodies were identified using serial dilutions: anti-PDGF- $\beta$ receptor B subunit, $1 \mu \mathrm{g} / \mathrm{ml}$ (reference 46; No. 1263-00, Genzyme Corp., Cambridge, MA); human endothelium EN4 (BIODESIGN International, Kennebunkport, ME), diluted 1:500 from stock; and human alpha-smooth muscle actin (Dako Corp.), $0.2 \mu \mathrm{g} / \mathrm{ml}$. The antibodies assessed for PDGF- $\alpha$ R reactivity were No. 1264-00 (Genzyme Corp.) and No. C6-132 (Upstate Biotechnology, Inc., Lake Placid, NY).

\section{Antibody competition}

Antibodies were competed with their immunizing PDGF homodimers on tissue sections to confirm specificity. 6C-51 and 3E-205 were tested against up to 100-fold molar excess PDGF-A $A_{L}$ and up to 15-fold molar excess PDGF-AAs. 1F-133 was tested against up to 50-fold, and 4E-4 against up to 100 -fold, molar excess PDGF-BB. All antigen/antibody mixtures were prepared the day before use and allowed to react overnight at $4^{\circ} \mathrm{C}$. The same procedure described above for light microscopy immunohistochemistry was used, substituting the competition mixes for the primary. Positive controls from serial sections were stained during the same run using the working concentrations of the antibodies also prepared and stored in the same manner as the antigen/antibody mixtures. Tissues chosen for competition were those previously showing optimum antibody reactions as well as $\mathrm{CHO}-\mathrm{AA}$ and $\mathrm{CHO}-\mathrm{BB}$ cell block sections. 

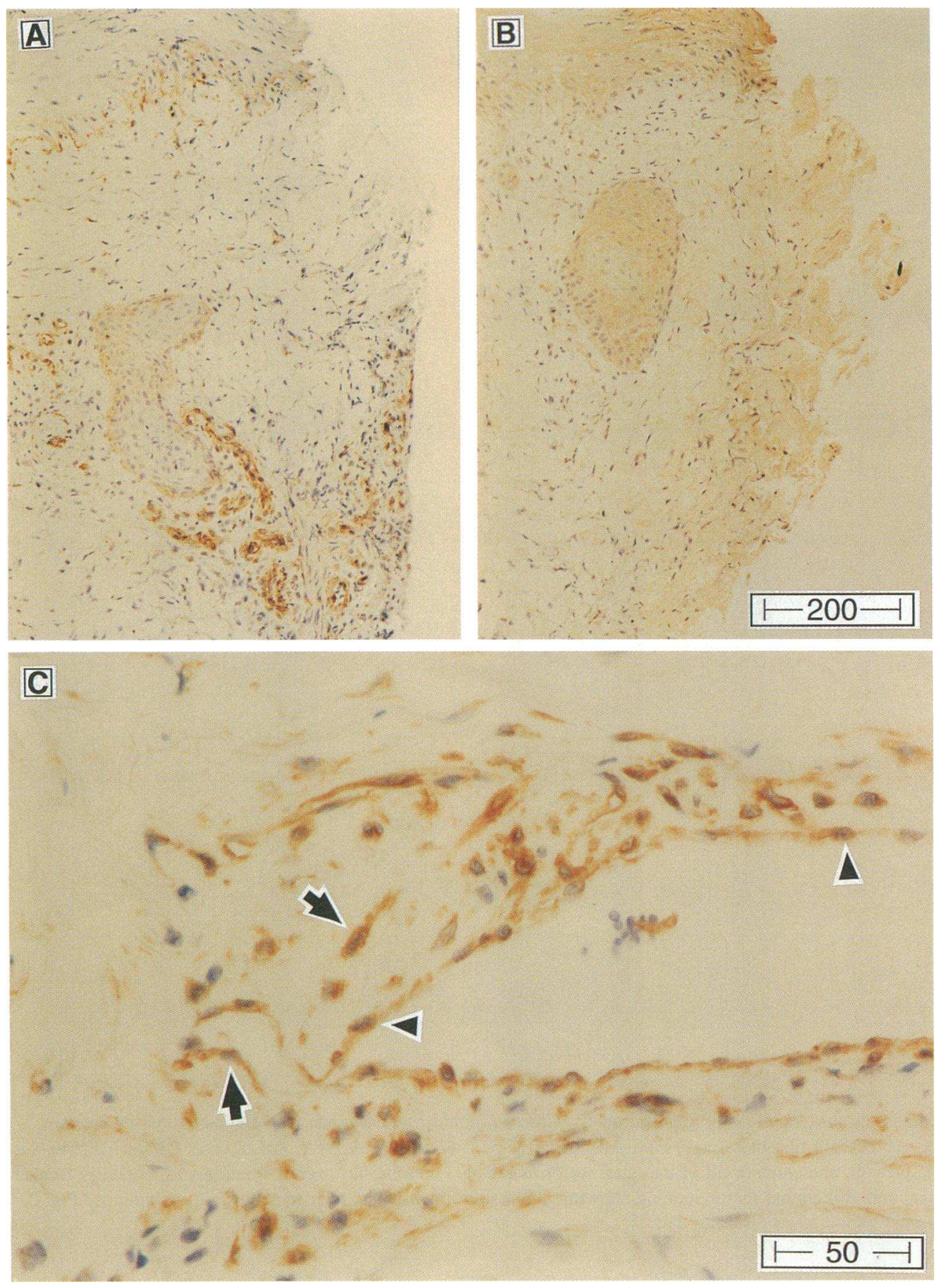

Figure 7. Identification of PDGF isoforms at the leading edge of day 8 rPDGF-BB-treated pressure ulcers. (A) PDGF-AA $\mathrm{L}_{\mathrm{L}}(6 \mathrm{C}-51)$ was detected in capillaries. $(B)$ PDGF$\mathrm{BB} / \mathrm{AB}$ (1F-133) was not detected. (C) Fibroblasts (arrows) in proximity to capillary (arrowhead) contained PDGF-AA $\mathrm{L}_{\mathrm{L}}$ (6C-51). Original magnification in $A$ and $B, \times 80$; original magnification in $C, \times 320$.

\section{Electron microscopy}

Ultrathin sections of LR White-embedded materials were collected on nickel grids for the subcellular localization of the PDGF homodimers. The sections were first hydrated for $30 \mathrm{~min}$ on droplets of wash buffer ( $0.8 \%$ BSA, $0.1 \%$ fish skin gelatin [Sigma Immunochemicals] in 50 $\mu \mathrm{M}$ Tris- $\mathrm{HCl}, 150 \mathrm{mM} \mathrm{NaCl}, \mathrm{pH}$ 7.6). The grids were then incubated for $2 \mathrm{~h}$ at room temperature in primary antibody diluted in wash buffer to the following concentrations: $4 \mathrm{E}-4,46,92$, and $460 \mu \mathrm{g} / \mathrm{ml} ; 3 \mathrm{E}-$ $205,40$ and $80 \mu \mathrm{g} / \mathrm{ml} ; 6 \mathrm{C}-51,116 \mu \mathrm{g} / \mathrm{ml} ; 1 \mathrm{~F}-133,79 \mu \mathrm{g} / \mathrm{ml})$. After incubation, the grids were briefly rinsed on several drops of wash buffer, then transferred to a goat anti-mouse secondary antibody conjugated to $10 \mathrm{~nm}$ colloidal gold (Amersham International). The gold-labeled secondary antibody was diluted $1: 25$ in $50 \mu \mathrm{M}$ Tris-buffered saline containing $1.0 \%$ goat serum and $0.1 \%$ gelatin. After $2 \mathrm{~h}$ at room temperature, the grids were rinsed first in wash buffer, then in distilled water.
To enhance contrast the sections were stained for $10 \mathrm{~min}$ in $2 \%$ aqueous uranyl acetate before examination on the electron microscope.

\section{Results}

Monoclonal antibody characterization. The monoclonal anti-

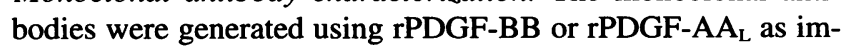
munogens. To assess their specificity and optimal titers, several assays were used (Table I). RIA, nitrocellulose-based immunoassay, BIAcore, and Western blots demonstrated which antibodies had unique specificities. CHO cells expressing rPDGF-BB or rPDGF-AA were used to identify four antibodies which reacted with tissue sections, and the BIAcore was used to confirm the specificity of binding. Two were generated using rPDGF- 

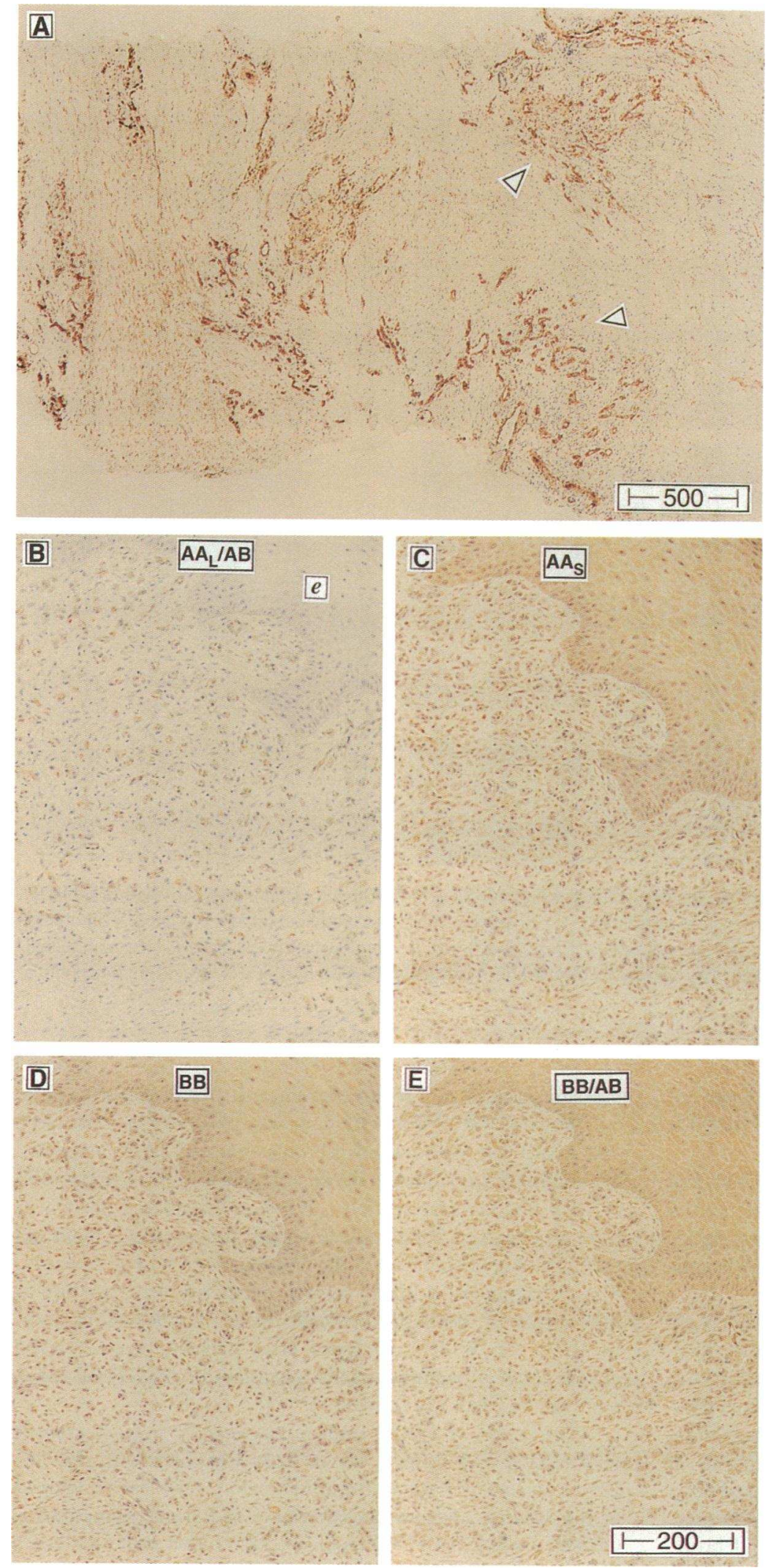

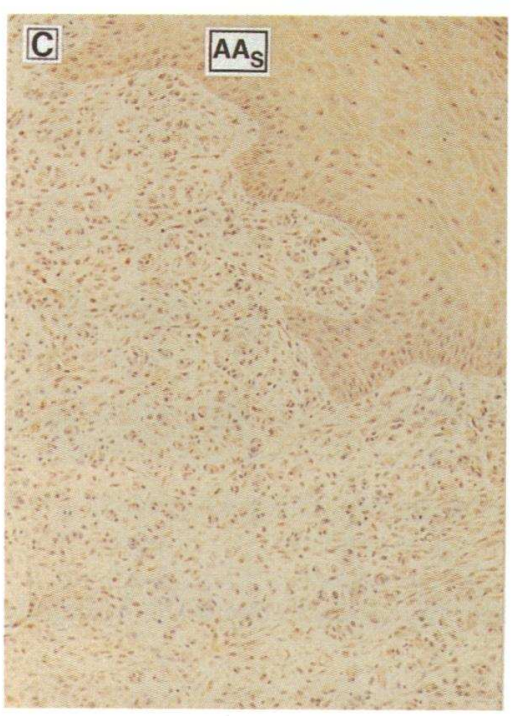

Figure 8. Identification of PDGF in maturing granulation tissue of rPDGF-BB-treated healing pressure ulcers. $(A)$ Healing ulcer after 2 wk of treatment showing PDGF$\mathrm{AA}_{\mathrm{L}}(6 \mathrm{C}-51)$ and $-\mathrm{AA}_{S}$ (3E-205, data not shown) in fibroblasts and capillaries (wound surface is to the left; original magnification, $\times 32$ ). Note the positive capillary beds (open arrowheads). After 4 wk of rPDGF-BB therapy, maturing granulation tissue was stained with $(B)$ anti- $\mathrm{AA}_{\mathrm{L}} / \mathrm{AB},(C)$ anti- $\mathrm{AA}_{\mathrm{s}} / \mathrm{AA}_{\mathrm{L}},(D)$ anti-BB, and $(E)$ anti-BB/AB. PDGF-AA $(C)$ and -BB $(D$ and $E)$ appear to be the predominant isoforms in maturing granulation tissue, while PDGF-AA $A_{L}$ and $\mathrm{AA}_{S}$ are present in less mature granulation tissue $(A) . e$, epithelium. Original magnification, $\times 80$.
$\mathrm{BB}$ as an immunogen (4E-4 and 1F-133), and two were made using rPDGF-AA $A_{L}$ (6C-51 and 3E-205) (Table I). 1F-133 and $6 \mathrm{C}-51$ both reacted with $\mathrm{AB}$ heterodimer as well as with their cognate ligands (Fig. 1). In addition, $6 \mathrm{C}-51$ reacted only with
$\mathrm{AA}_{\mathrm{L}}$, while $3 \mathrm{E}-205$ reacted with $\mathrm{AA}_{S}$ and $\mathrm{AA}_{\mathrm{L}}$, suggesting the epitope for $6 \mathrm{C}-51$ requires the $\mathrm{COOH}$-terminal 16 amino acids of the A chain. For example, in the RIA, 6C-51 showed no reactivity toward $\mathrm{AA}_{S}$, while it was highly reactive 

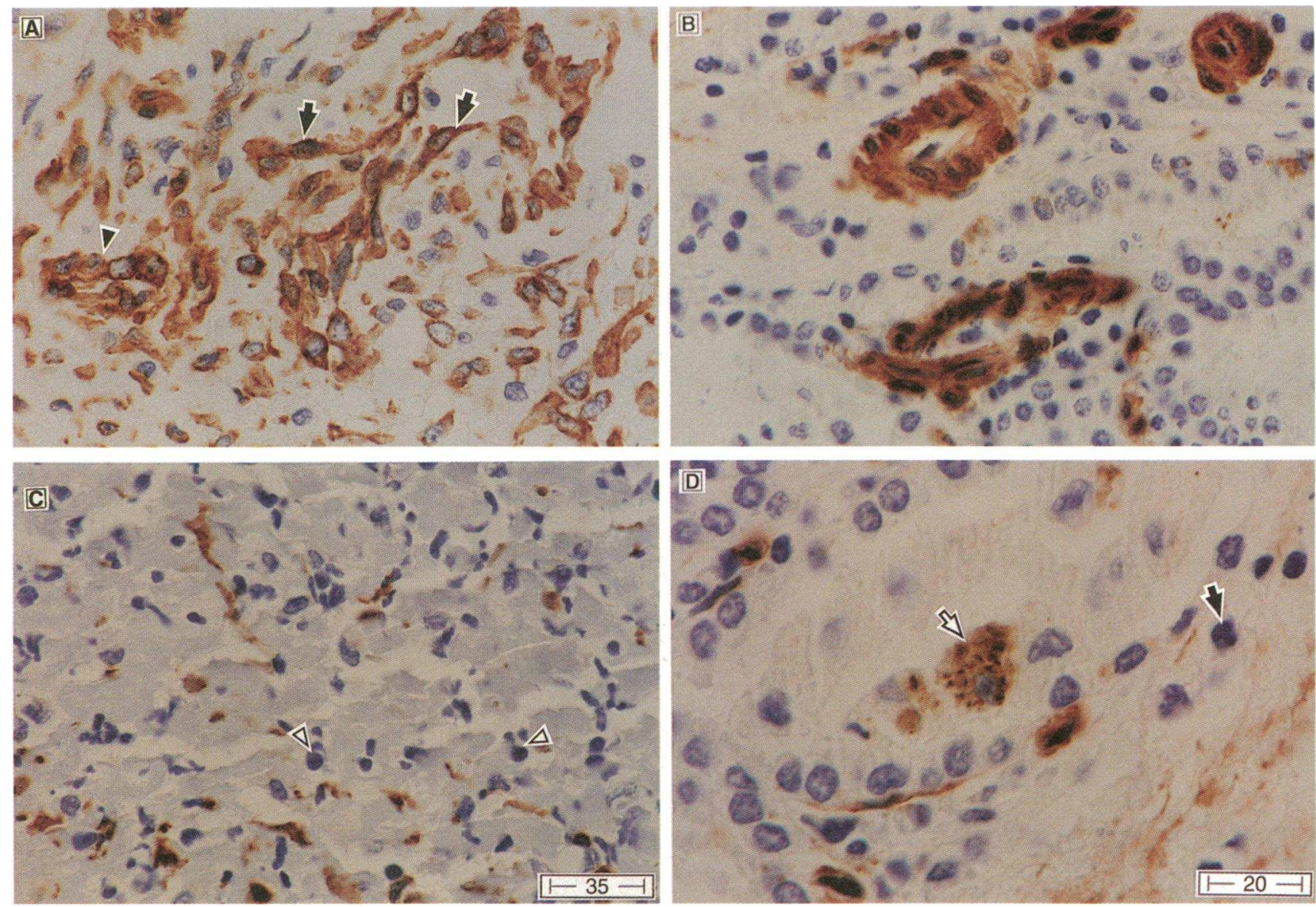

Figure 9. Localization of PDGF-AA $A_{L}$ in specific cell types within healing wounds using 6C-51. (A) PDGF-AA $A_{L}$ staining of activated fibroblasts, $(B) \mathrm{AA}_{\mathrm{L}}$ in endothelial cells and smooth muscle cells/pericytes within capillaries. $(C)$ Absence of PDGF in lymphocytes and presence in fibroblasts (D) Presence of PDGF-AA $\mathrm{A}_{\mathrm{L}}$ in wound macrophages and absence in neutrophils. Closed arrows in A, fibroblasts; closed arrowheads, endothelial cells; open arrowheads, lymphocytes; open arrow, macrophage; short arrow, neutrophil. Original magnification in $A-C, \times 480$; original magnification in $D, \times 800$.

( $>1: 10,000$ ) when $\mathrm{AA}_{\mathrm{L}}$ was used as the plate antigen (data not shown $)$. In contrast, 3E-205 was highly reactive $(>1: 10,000)$ toward both forms.

The BIAcore confirmed the cross-reactivity of $6 \mathrm{C}-51$ and $1 \mathrm{~F}-133$ with rPDGF-AB and the lack of heterodimer crossreactivity with $3 \mathrm{E}-205$ and $4 \mathrm{E}-4$. Thus, the antibodies are designated as anti- $\mathrm{AA}_{\mathrm{L}} / \mathrm{AB}(6 \mathrm{C}-51)$, anti-AA $/ \mathrm{AA}_{\mathrm{L}}(3 \mathrm{E}-205)$, antiBB (4E-4), and anti-BB/AB (1F-133) (Table I).

Identification of PDGF isoforms in normal skin and acute and chronic wounds. Normal skin contained scattered fibroblasts and capillaries that reacted more strongly with anti- $\mathrm{AA}_{\mathrm{L}} /$ $\mathrm{AB}$ than anti-BB/AB, suggesting largely PDGF-AA was present (Fig. 2). In an actively healing wound such as granulation tissue generated after surgery, tremendous upregulation of PDGF-AA $A_{L}$ within fibroblasts and capillaries was detected (Fig. 3). Little PDGF-BB (Fig. 3), -AB, or $-A A_{s}$ was observed. Chronic pressure ulcers that received radical (surgical) debridement $48 \mathrm{~h}$ before the biopsy similarly demonstrated tremendous upregulation of PDGF-AA $A_{L}$, although some PDGF-AB and $\mathrm{BB}$ isoforms were present also (Fig. 4).

To confirm the specificity of the antibodies, competition experiments were performed that demonstrated antibody reactivity could be blocked by the appropriate ligand(s) (Fig. 5).

In contrast to acute healing wounds, chronic nonhealing pressure ulcers had a relative absence of PDGF isoforms (Fig. 6). Weak PDGF isoform staining was observed in most large and small vessels; however, fibroblasts were largely negative. To control for potentially decreased penetration of antisera in chronic wound tissue sections, anti-von Willebrand factor was used and showed equal stain intensity for vessels in both actively healing (Fig. 3, inset) and chronic wounds (Fig. 6, inset). Thus, differences in PDGF antisera reactivity were not due to differences in the tissue between different types of wounds. Identical von Willebrand factor stain intensity was observed also in actively healing wounds regardless of rPDGF-BB-treatment status (data not shown).

Expression of PDGF isoforms in chronic wounds treated with $r P D G F-B B$. After 1 wk of daily treatment with rPDGFBB $\left(1 \mu \mathrm{g} / \mathrm{cm}^{2} / \mathrm{d}\right)$, an active inflammatory response developed at the leading edge of the wound. Capillaries expressed increased amounts of PDGF-AA $A_{L}$ and fibroblasts near capillaries were preferentially positive for PDGF-AA $A_{L}$ (Fig. 7). Little PDGF-BB or - $\mathrm{AB}$ was present, and many fibroblasts were negative for PDGF. However, after 2 wk of rPDGF-BB therapy, when procollagen type $I$ synthesis is greatly increased in these healing wounds (41), high levels of both PDGF-AA $A_{L}$ and -AA were detected in fibroblasts and capillaries throughout maturing granulation tissue (Fig. $8 A$ ). After 4 wk of therapy, when 

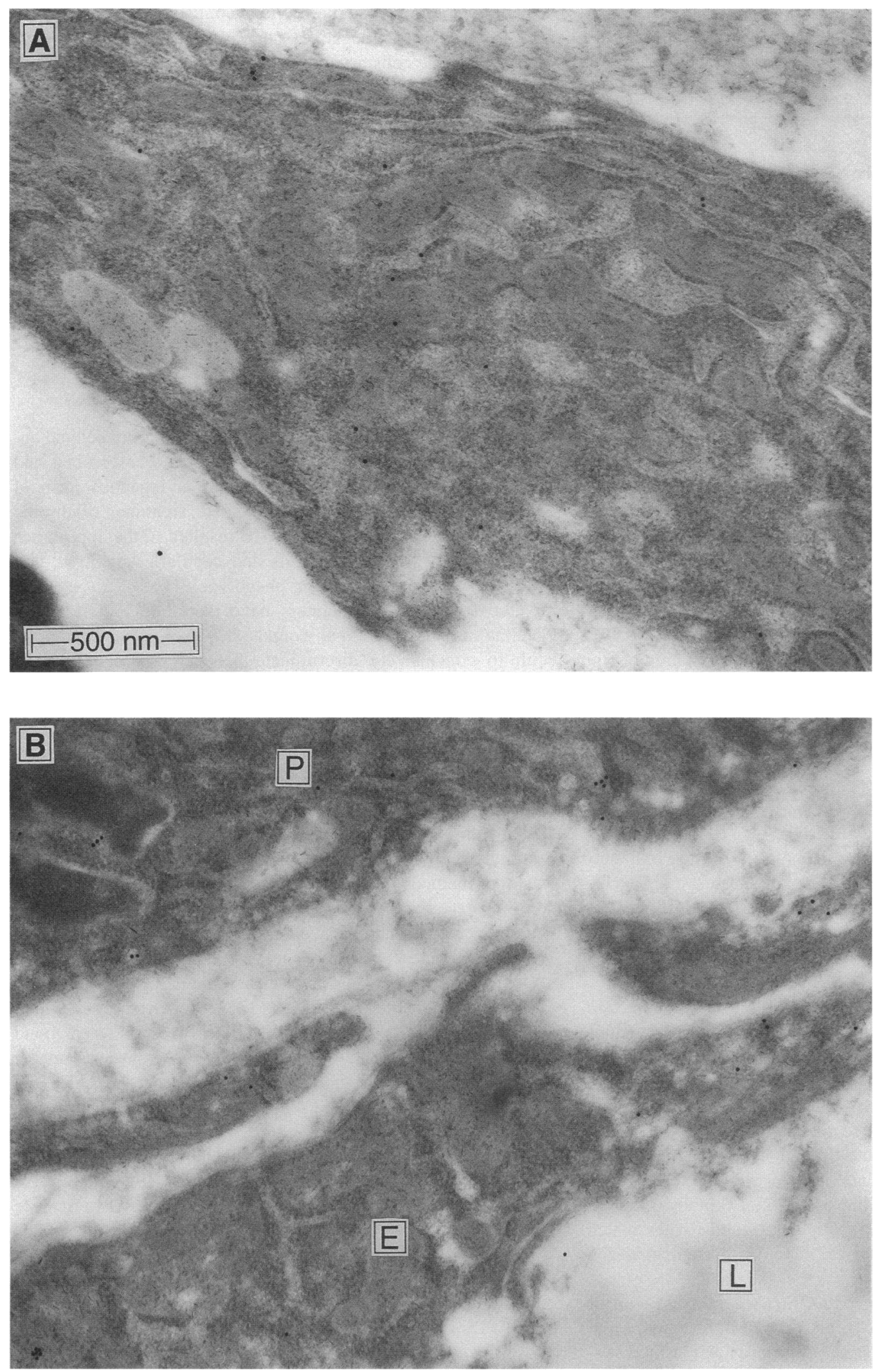

Figure 10. Detection of PDGF-AA in $(A)$ fibroblasts and $(B)$ endothelial cells $(E)$ and pericytes $(P)$ in day 15 healing wounds by immunoelectron microscopy using $3 \mathrm{E}-205$. $L$, lumen. 
Table II. Immunoelectron Microscopic Detection of PDGF in Specific Cell Types

\begin{tabular}{llrc}
\hline PDGF isoform antibody & Cell type* & $N$ & $\begin{array}{c}\text { Gold particle } \\
\text { density }\end{array}$ \\
\hline & & & $\left(\# / \mu m^{2} \text { cell }\right)^{ \pm}$ \\
Anti-AA $_{S} / \mathrm{AA}_{\mathrm{L}}$ (3E-205) & Fibroblasts & 20 & $2.0 \pm 0.8$ \\
& Endothelium & 20 & $1.9 \pm 0.6$ \\
& Pericytes & 7 & $1.9 \pm 0.8$ \\
Anti-BB (4E-4) & Fibroblasts & 20 & $0.7 \pm 0.2$ \\
& Endothelium & 20 & $0.9 \pm 0.4$ \\
& Pericytes & 8 & $0.6 \pm 0.2$ \\
\hline
\end{tabular}

* Cells were identified on the basis of established morphological criteria (see Methods). ${ }^{\ddagger}$ Mean \pm SD of gold particles per square micron of each specified cell type; $N$ is the number of cells counted.

granulation tissue is more mature, PDGF-AA $A_{s}$ and $-\mathrm{BB}$ were expressed at higher levels in fibroblasts than PDGF- $A A_{L}$ or $-A B$, which were present primarily in capillaries (Fig. 8, $B-E)$.

Cellular localization of PDGF isoforms within healing wounds. PDGF-AA is expressed predominantly in activated fibroblasts and capillaries within healing wounds (Fig. $9 \mathrm{~A}$ ). Within capillaries, endothelial cells clearly show staining (Fig. $9 \mathrm{~B}$ ). In addition, pericytes and smooth muscle cells appeared to be positive in some vessels as well. Neutrophils and lymphocytes contained no PDGF (Fig. $9 C$ ). Variable numbers of monocytes/macrophages, identified by morphological criteria, contained PDGF-AA $\mathrm{A}_{\mathrm{L}}$ and appeared to be a small contributor to the total wound PDGF (Fig. $9 \mathrm{D}$ ). Regenerating keratinocytes in a few wounds contained PDGF-AA $/ \mathrm{BB}$, but this was not a consistent finding in all wounds (Fig. 8, B-E). Immunoelectron microscopy confirmed the specific presence of PDGFAA in fibroblasts, endothelial cells, and pericytes (Fig. 10, $A$ and $B$ ). Quantitation of gold particle densities indicated that more PDGF-AA was present within these cell types, compared with PDGF-BB (Table II).

Localization of PDGF- $\beta$ receptor within normal skin and granulation tissue. The findings that acute and chronic wounds respond to exogenous $\mathrm{PPDGF}-\mathrm{BB}$ and, when actively healing, contain high levels of PDGF-AA $A_{L}$ suggests that either only PDGF- $\alpha$ receptors are present (which can bind all three isoforms), or that both $\alpha$ and $\beta$ receptors are present, since PDGF$\beta$ receptors would bind only the exogenous PDGF-BB and not the endogenous PDGF-AA. Since receptor staining required the use of frozen sections, we had to use normal skin and granulation tissue obtained from acute surgical wound tissues which were used earlier to characterize PDGF isoform expression (Figs. 2 and 3).

We were not able to detect PDGF- $\alpha$ receptors in skin or wounds with the available reagents. PDGF- $\beta$ receptors were localized in normal skin on dermal fibroblasts and around vessels (Fig. $11 \mathrm{~A}$ ). Using EN4 and smooth muscle cell actin antibodies, both endothelial cells and pericytes and/or smooth muscle cells could be distinguished (Fig. $11 B$ ). Epidermis was negative for PDGF- $\beta$ receptors (Fig. $11 C$ ). The vascular PDGF- $\beta$ receptor staining was often colocalized with endothelial EN-4 staining, suggesting that microvascular endothelial cells contain PDGF- $\beta$ receptors (Fig. $12 A$ ). Smooth muscle cell actin staining of serial sections confirmed the presence of PDGF- $\beta$ receptor-negative perivascular pericytes and/or smooth muscle cells around some vessels (Fig. $12 \mathrm{~B}$ ). Intense PDGF- $\beta$ receptor expression was detected in actin-negative fibroblast-like cells intimately associated with vessels, suggesting that it is fibroblasts around small blood vessels that express the PDGF- $\beta$ receptor and not pericytes or smooth muscle cells. Larger arteries contained PDGF- $\beta$ receptor-positive cells only within the adventitia (Fig. $12 \mathrm{C}$ ). Smooth muscle cells and endothelial cells in large arteries had no detectable PDGF- $\beta$ receptor staining (Fig. $12 C$ ). PDGF- $\beta$ receptor staining in granulation tissue showed the same pattern as observed in normal skin (data not shown).

\section{Discussion}

Using newly developed PDGF isoform-specific monoclonal antibodies, acute and chronic human wounds were probed and PDGF-AA was identified as the major endogenous form of PDGF synthesized within the wound bed. Treatment of chronic wounds with exogenous rPDGF-BB resulted in the appearance of PDGF-AA within fibroblasts and capillaries by 2 wk and was associated with a healing phenotype (41).

Several other investigators have identified PDGF within healing human and animal wounds; however, it has been difficult to conclusively discriminate between PDGF-AA, - AB, and $-\mathrm{BB}$ dimers, and identification of the long and short forms of PDGF-AA has not been possible $(9,15,47)$. Previous investigators have used a monoclonal antibody directed toward PDGF-BB/AB $(15,48)$ or a panel of antibodies (47). We would interpret findings of PDGF-BB/AB within wounds cautiously, because all our isoform-specific antibodies cross-reacted with the nonimmunogen isoforms at higher antibody concentrations. With titering and establishment of reproducible staining methods, as performed in this study, a sufficient window of reactivity permitted isoform-specific staining. In the human acute and chronic wounds in our study, PDGF-BB and PDGF-AB were considerably less prevalent than PDGF-AA $A_{L}$. $A$ recent study that analyzed acute human wound fluid also found predominantly PDGF-AA (12). Another study in which wound fluid from chronic pressure ulcers was analyzed found variable amounts of PDGF present, but the assay was unable to discriminate among the isoforms (49). Recently, Ansel and co-workers (47) identified PDGF-AA in provisional matrix within experimental human wounds. They found minimal staining of PDGF-BB also consistent with our findings. However, they were unable to discriminate between PDGF-AA isoforms.

PDGF-AA $A_{L}$ binds to extracellular matrix in tissue culture far more than PDGF-AAs $(34,50,51)$. The carboxy terminus of PDGF-AA $A_{L}$ is highly basic and interacts with acidic matrix molecules such as glycosaminoglycans and heparan sulfate-proteoglycan (for review see reference 51). Thus, the matrix may store PDGF-AA $A_{L}$ for later paracrine or autocrine use. PDGF$\mathrm{AA}_{\mathrm{S}}$, in contrast, is more efficiently secreted by cells (52). PDGF-BB, which is not alternatively spliced, contains a highly basic matrix binding carboxy terminus as well and is not efficiently secreted $(33,34)$. The biological significance of PDGFAA splice variants and PDGF isoforms that can differentially bind matrix remains poorly understood $(48,53-55)$. However, the present results suggest that early in wound healing PDGF$\mathrm{AA}_{\mathrm{L}}$ is present in greatest quantities, while in the maturing 

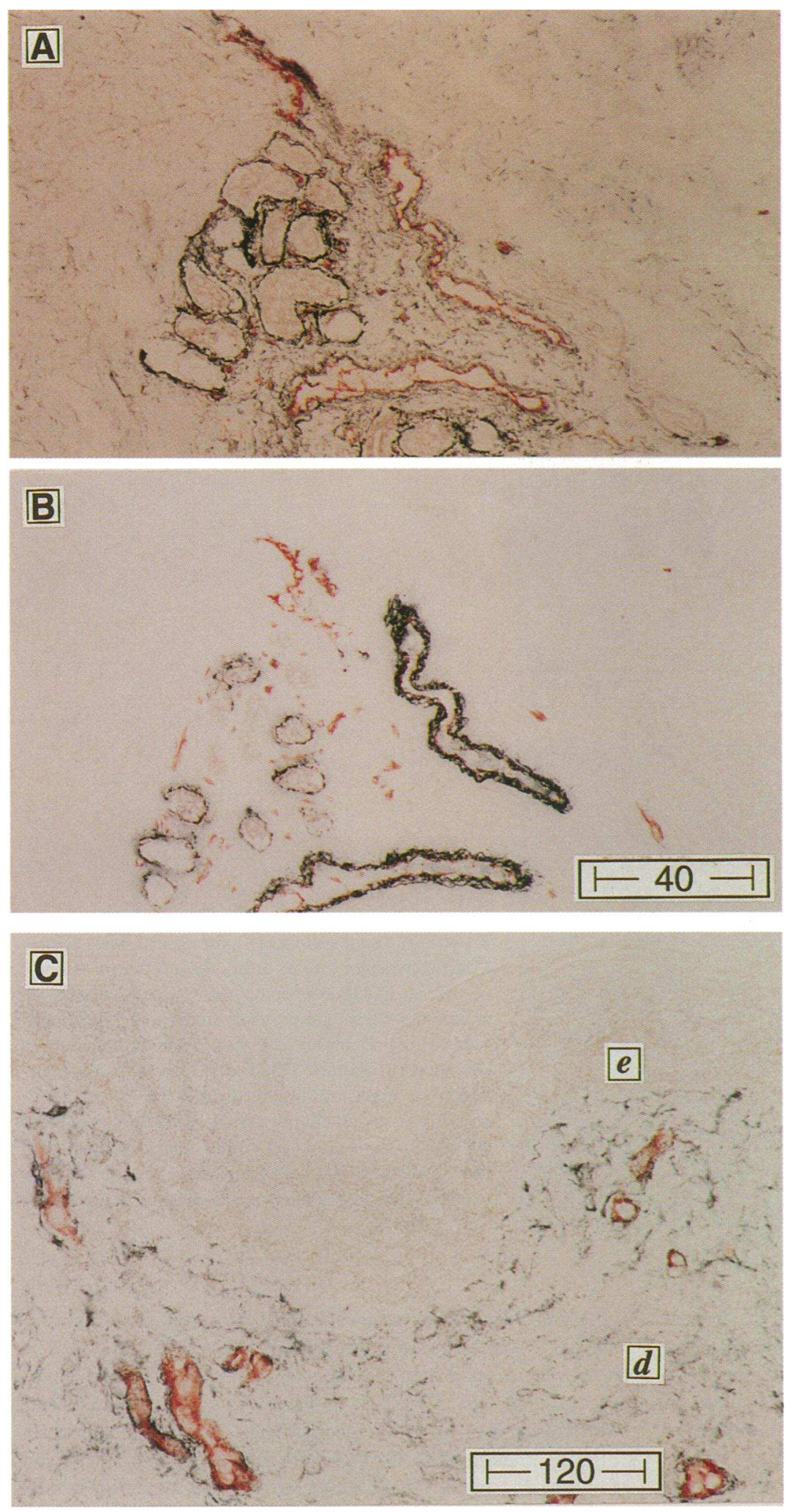

Figure 11. Detection of PDGF- $\beta$ receptors within skin. $(A)$ Human skin stained with antibodies to the PDGF- $\beta$ receptor (black) and to endothelium (red). PDGF- $\beta$ receptor was expressed in fibroblasts, around vessels, and surrounding glands. $(B)$ An adjacent section of human skin stained with antibodies to smooth muscle cell actin (black) and endothelium (red). The dermal fibroblasts are negative but smooth muscle cells and pericytes around many blood vessels are clearly stained. $(C)$ Higher magnification of skin demonstrating that epidermis $(e)$ did not stain for the PDGF- $\beta$ receptor. Fibroblasts and perivascular cells in the dermis $(d)$ were positive (black) for PDGF- $\beta$ receptor. Endothelium stained red. Original magnification in $A$ and $B, \times 31$; original magnification in $C$, $\times 100$. granulation tissue of healing wounds, well-secreted PDGF-AAs is prevalent.

Fibroblasts and capillaries appeared to be the greatest sources of PDGF-AA $\mathrm{L}_{\mathrm{L}}$ within healing wounds. Neutrophils and lymphocytes produced no PDGF. Macrophages were not prominent in these noninfected wounds, and the wounds healed via the deposition of extracellular matrix and formation of granulation tissue, which are fibroblast- and endothelial cell-mediated processes $(6,21,41)$. Within capillaries, PDGF-AA $A_{L}$ was clearly detected within endothelial cells. Pericytes were more difficult to identify, and intracellular PDGF within pericytes was not definitively established. 

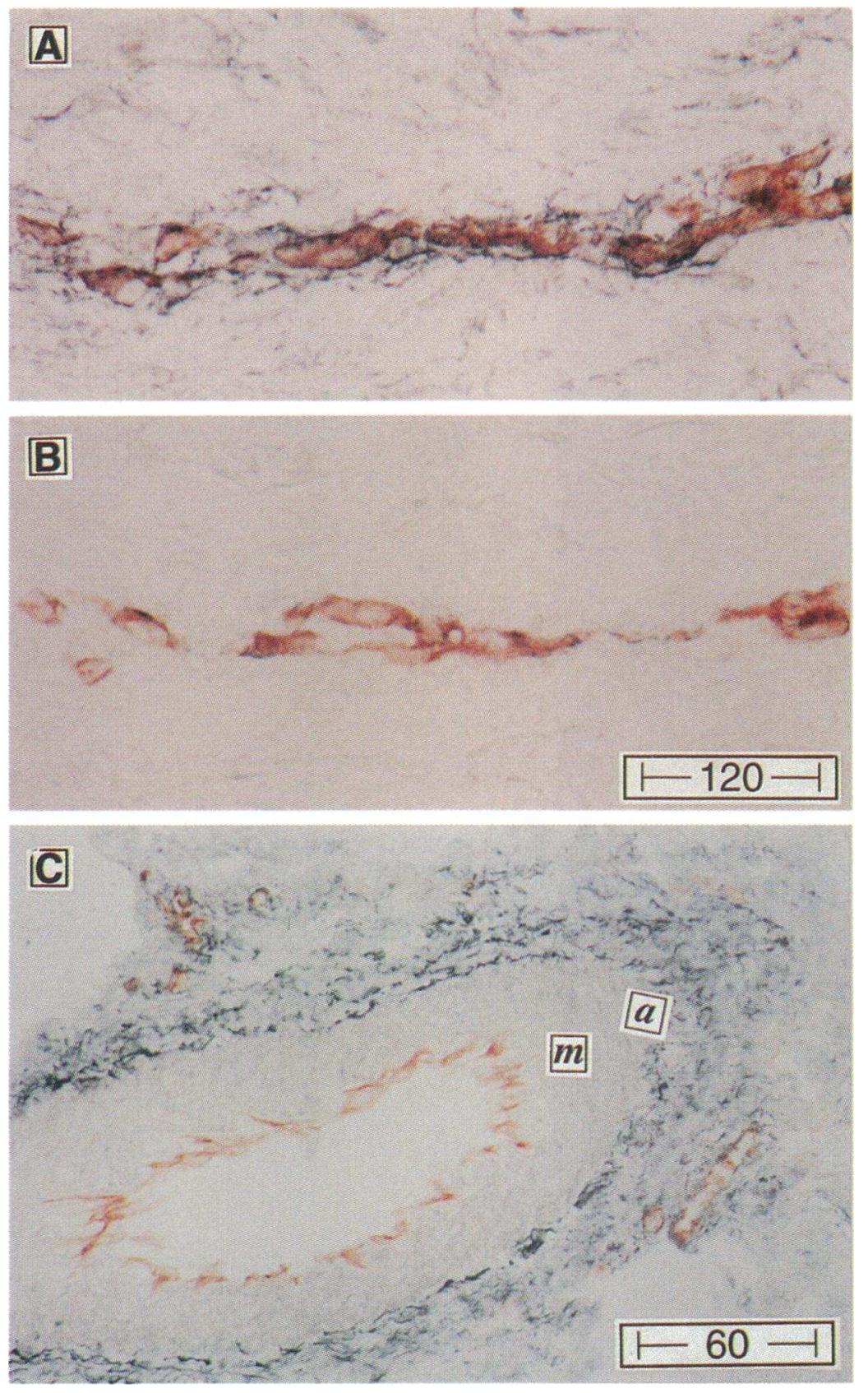

Figure 12. Serial sections of skin stained black for PDGF- $\beta$ receptor $(A)$ or actin $(B)$ and red for endothelium. In $A$, PDGF- $\beta$ receptor-positive cells concentrated around this vessel are probably fibroblasts which do not stain for smooth muscle cell actin. Some endothelial cells $(A)$ appear to express PDGF- $\beta$ receptors. $(C)$ Section through a larger artery stained for PDGF- $\beta$ receptor (black) and endothelium ( $r e d$ ) in which the smooth muscle cells in the media $(m)$ do not appear to stain for $\beta$ receptor. Adventitial cells $(a)$ stain intensely. Original magnification in $A$ and $B, \times 100$; original magnification in $C, \times 50$.
Keratinocytes infrequently, and inconsistently, showed some staining, in contrast to some $(9,47)$ but not all $(15)$ previous reports. This difference may be due to differences in reagents, staining methodologies, and species. For instance, in porcine wounds, PDGF- $\beta$ receptor was also found in epidermis (9), in contrast to other studies $(15,47$, this report $)$.

All PDGF isoforms can bind their respective $\alpha$ and $\beta$ receptors, affect signal transduction, activate early genes, and induce proliferation. The $\alpha$ receptor, however, which can bind all isoforms, appears unable to mediate chemotaxis (56), although this remains controversial (57). The $\beta$ receptor, which binds only PDGF-BB with high affinity, clearly mediates cellular migration in cells that bear this receptor. Reuterdahl and co-workers (15) have identified $\beta$ receptors within healing human wounds, although they could not precisely localize the cell types. Another study from this lab did localize $\beta$ receptors to pericytes (14). They suggested that macrophages (identified as CD68 positive) introduced PDGF-BB/AB to wounds (15); however, in our experience healing, noninfected ulcers have a predominance of neovessels and procollagen type I-containing fibroblasts (41), and not macrophages, which contribute significant amounts of PDGF-AA $A_{L}$ into the wound bed. The reasons for this discrepancy may relate to different types of wounds analyzed, to their use of a BB/AB-specific antibody, or that CD68 may not be fully specific for macrophages (58).

The present results show that fibroblasts and probably microvascular endothelial cells in skin and granulation tissue express PDGF- $\beta$ receptors, suggesting that therapeutically delivered rPDGF-BB may stimulate repair by directly stimulating fibroblasts and endothelial cells. The role for endogenously produced PDGF-AA $A_{L}$ is less clear and will need to await the development of improved reagents that can better localize PDGF- $\alpha$ 
receptors in wounds. The available evidence suggests that PDGF-AA $A_{L}$, which can bind matrix, is more prevalent earlier in the repair process, while PDGF-AA $A_{s}$ is found later in mature granulation tissue. These results raise the possibility that the two PDGF-AA splice variants have unique biological activities.

\section{Acknowledgments}

We appreciate the technical assistance of Diane Duryea. We thank Margery Nicolson for helpful discussions on antibody generation. We thank Joan Bennett for manuscript preparation and Jennifer Keysor for illustrations. We also thank C.-H. Heldin and K. Funa for anti-PDGF$\beta$ receptor antisera used in preliminary experiments.

\section{References}

1. Ross, R. 1968. The fibroblast and wound repair. Biol. Rev. Camb. Philos. Soc. 43:51-96.

2. Pierce, G. F., and T. A. Mustoe. 1995. Pharmacologic enhancement of wound healing. Annu. Rev. Med. 46:467-481.

3. Deuel, T. F., R. Kawahara, T. A. Mustoe, and G. F. Pierce. 1991. Growth factors and wound healing: platelet-derived growth factor as a model cytokine. Annu. Rev. Med. 42:567-584.

4. Clark, R. A. 1993. Basics of cutaneous wound repair. J. Dermatol. Surg. Oncol. 19:693-706.

5. Mustoe, T. A., G. F. Pierce, C. Morishima, and T. F. Deuel. 1991. Growth factor induced acceleration of tissue repair through direct and inductive activities in a rabbit dermal ulcer model. J. Clin. Invest. 87:694-703.

6. Pierce, G. F., J. Tarpley, D. Yanagihara, T. A. Mustoe, G. M. Fox, and A. Thomason. 1992. PDGF-BB, TGF- $\beta 1$, and basic FGF in dermal wound healing: neovessel and matrix formation and cessation of repair. Am. J. Pathol. 140:13751388.

7. Leibovich, S. J., and R. Ross. 1975. The role of the macrophage in wound repair. Am. J. Pathol. 78:71-100.

8. Paulsson, Y., A. Hammacher, C.-H. Heldin, and B. Westermark. 1987 Possible positive autocrine feedback in the prereplicative phase of human fibroblasts. Nature (Lond.). 328:715-717.

9. Antoniades, H. N., T. Galanopoulos, J. Neville-Golden, C. P. Kiritsy, and S. E. Lynch. 1991. Injury induces in vivo expression of platelet-derived growth factor (PDGF) and PDGF-receptor mRNAs in skin epithelial cells and PDGF mRNA in connective tissue fibroblasts. Proc. Natl. Acad. Sci. USA. 88:565-569.

10. Pierce, G. F., T. A. Mustoe, J. Lingelbach, V. R. Masakowski, G. Griffin,

R. M. Senior, and T. F. Deuel. 1989. Platelet-derived growth factor and transforming growth factor $\beta$ induce in vivo and in vitro tissue repair activities by unique mechanisms. J. Cell Biol. 109:429-440.

11. Terracio, L., L. Rönnstrand, A. Tingström, K. Rubin, L. Claesson-Welsh, K. Funa, and C.-H. Heldin. 1988. Induction of platelet-derived growth factor receptor expression in smooth muscle cells and fibroblasts upon tissue culturing. J. Cell Biol. 107:1947-1957.

12. Soma, Y., V. Dvonch, and G. R. Grotendorst. 1992. Platelet-derived growth factor AA homodimer is the predominant isoform in human platelets and acute human wound fluid. FASEB (Fed. Am. Soc. Exp. Biol.) J. 6:2996-3001.

13. Shaw, R. J., D. E. Doherty, A. G. Ritter, S. H. Benedict, and R. A. F. Clark. 1990. Adherence-dependent increase in human monocyte PDGF(B) mRNA is associated with increases in c-fos, c-jun, and EGR2 mRNA. J. Cell Biol. 111:2139-2148.

14. Sundberg, C., M. Ljungström, G. Lindmark, B. Gerdin, and K. Rubin. 1993. Microvascular pericytes express platelet-derived growth factor- $\beta$ receptors in human healing wounds and colorectal adenocarcinoma. Am. J. Pathol. 143:1377-1388.

15. Reuterdahl, C., C. Sundberg, K. Rubin, K. Funa, and B. Gerdin. 1993. Tissue localization of $\beta$-receptors for platelet-derived growth factor and plateletderived growth factor B chain during wound repair in humans. J. Clin. Invest. 91:2065-2075.

16. Nagaoka, I., A. Someya, K. Iwabuchi, and T. Yamashita. 1991. Comparative studies on the platelet-derived growth factor-A and -B gene expression in human monocytes. Comp. Biochem. Physiol. 100B:313-319.

17. Hart, C. E., M. Bailey, D. A. Curtis, S. Osborn, E. Raines, R. Ross, and J. W. Forstrom. 1990. Purification of PDGF-AB and PDGF-BB from human platelet extracts and identification of all three PDGF dimers in human platelets. Biochemistry. 29:166-172.

18. Grotendorst, G. R., G. R. Martin, D. Pencev, J. Sodek, and A. K. Harvey. 1985. Stimulation of granulation tissue formation by platelet-derived growth factor in normal and diabetic rats. J. Clin. Invest. 76:2323-2329.

19. Greenhalgh, D. G., K. H. Sprugel, M. J. Murray, and R. Ross. 1990.
PDGF and FGF stimulate wound healing in the genetically diabetic mouse. Am. J. Pathol. 136:1235-1246.

20. Pierce, G. F., T. A. Mustoe, R. M. Senior, J. Reed, G. L. Griffin, A. Thomason, and T. F. Deuel. 1988. In vivo incisional wound healing augmented by platelet-derived growth factor and recombinant c-sis gene homodimeric proteins. J. Exp. Med. 167:974-987.

21. Pierce, G. F., J. Vande Berg, R. Rudolph, J. Tarpley, and T. A. Mustoe. 1991. PDGF-BB and TGF- $\beta 1$ selectively modulate glycosaminoglycans, collagen, and myofibroblasts in excisional wounds. Am. J. Pathol. 138:629-646.

22. Quaglino, D., Jr., L. B. Nanney, R. Kennedy, and J. M. Davidson. 1990. Transforming growth factor $\beta$ stimulates wound healing and modulates extracellular matrix gene expression in pig skin. I. Excisional wound model. Lab. Invest. 63:307-319.

23. Sprugel, K. H., J. M. McPherson, A. W. Clowes, and R. Ross. 1987. Effects of growth factors in vivo. I. Cell ingrowth into porous subcutaneous chambers. Am. J. Pathol. 129:601-613.

24. D'Amore, P. A., and S. R. Smith. 1993. Growth factor effects on cells of the vascular wall: a survey. Growth Factors. 8:61-75.

25. Forsberg, K., I. Valyi-Nagi, C.-H. Heldin, M. Herlyn, and B. Westermark 1993. Novel role for PDGF in oncogenesis is suggested by the development of a vascular connective tissue stroma in xenotransplanted human melanoma producing PDGF-BB. Proc. Natl. Acad. Sci. USA. 90:393-397.

26. Golden, M. A., Y. P. T. Au, T. R. Kirkman, J. N. Wilcox, E. W. Raines, R. Ross, and A. W. Clowes. 1991. Platelet-derived growth factor activity and mRNA expression in healing vascular grafts in baboons. J. Clin. Invest. 87:406414.

27. Broadley, K. N., A. M. Aquino, S. C. Woodward, A. Buckley-Sturrock, Y. Sato, D. B. Rifkin, and J. M. Davidson. 1989. Specific antibodies implicate basic fibroblast growth factor in normal wound repair. Lab. Invest. 61:571-575.

28. Ross, R., J. A. Glomset, B. Kariya, and L. Harker. 1974. A plateletdependent serum factor that stimulates the proliferation of arterial smooth muscle cells in vitro. Proc. Natl. Acad. Sci. USA. 71:1207-1210.

29. Kohler, N., and A. Lipton. 1974. Platelets as a source of fibroblast growthpromoting activity. Exp. Cell Res. 87:297-301.

30. Collins, T., D. T. Bonthron, and S. H. Orkin. 1987. Alternative RNA splicing affects function of encoded platelet-derived growth factor A chain. Nature (Lond.). 328:621-624.

31. Tong, B. D., D. E. Auer, M. Jaye, J. M. Kaplow, G. Ricca, E. McConathy, W. Drohan, and T. F. Deuel. 1987. cDNA clones reveal differences between human glial and endothelial cell platelet-derived growth factor A-chains. Nature (Lond.). 328:619-621.

32. Matoskova, B., F. Rorsman, V. Svensson, and C. Betsholtz. 1989. Alternative splicing of the platelet-derived growth factor A-chain transcript occurs in normal as well as tumor cells and is conserved among mammalian species. Mol. Cell. Biol. 9:3148-3150.

33. Östman, A., G. Bäckström, N. Fong, C. Betsholtz, C. Wernstedt, U. Hellman, B. Westermark, P. Valenzuela, and C.-H. Heldin. 1989. Expression of three recombinant homodimeric isoforms of PDGF in Saccharomyces cerevisiae: evidence for differences in receptor binding and functional activities. Growth Factors. 1:271-281.

34. Kelly, J. L., A. Sánchez, G. S. Brown, C. N. Chesterman, and M. J. Sleigh. 1993. Accumulation of PDGF-B and cell-binding forms of PDGF-A in the extracellular matrix. J. Cell Biol. 121:1153-1163.

35. Hart, C. E., J. W. Forstrom, J. D. Kelly, R. A. Seifert, R. A. Smith, R. Ross, M. J. Murray, and D. F. Bowen-Pope. 1988. Two classes of PDGF receptor recognize different isoforms of PDGF. Science (Wash. DC). 240:1529-1531.

36. Heldin, C. H., G. Backsrom, A. Ostman, A. Hammacher, L. Ronnstrand, K. Rubin, M. Nister, and B. Westmark. 1988. Binding of different dimeric forms of PDGF to human fibroblasts: evidence for two separate receptor types. $E M B O$ (Eur. Mol. Biol. Organ.) J. 7:1387-1393.

37. Matsui, T., J. H. Pierce, T. P. Fleming, J. S. Greenberger, W. J. LaRochelle, M. Ruggiero, and S. A. Aaronson. 1989. Independent expression of human alpha or beta platelet-derived growth factor receptor cDNAs in a native hematopoietic cell leads to functional coupling with mitogenic and chemotactic signaling pathways. Proc. Natl. Acad. Sci. USA. 86:8314-8318.

38. Ericksson, A., A. Siegbahn, B. Westermark, C. H. Heldin, and L. ClaessonWelsh. 1992. PDGF-alpha and -beta receptors activate unique and common signal transduction pathways. EMBO (Eur. Mol. Biol. Organ.) J. 11:543-550.

39. Robson, M. C., L. G. Phillips, A. Thomason, L. F. Robson, and G. F. Pierce. 1992. Platelet-derived growth factor-BB in chronic pressure ulcers. Lancet. 339:23-25.

40. Mustoe, T. A., N. R. Cutler, R. M. Allman, P. S. Goode, T. F. Deuel, J. A. Krause, M. Bear, C. M. Serdar, and G. F. Pierce. 1994. A phase II study to evaluate recombinant PDGF-BB in the treatment of stage III/IV pressure ulcers. Arch. Surg. 129:213-219.

41. Pierce, G. F., J. E. Tarpley, R. M. Allman, P. S. Goode, C. S. Serdar, B. Morris, T. A. Mustoe, and J. Vande Berg. 1994. Tissue repair processes in healing chronic pressure ulcers treated with recombinant platelet-derived growth factor BB. Am. J. Pathol. 145:1399-1410.

42. Yeh, H.-J., G. F. Pierce, and T. F. Deuel. 1987. Ultrastructural localization 
of a PDGF/v-sis-related protein(s) in both cytoplasm and nucleus of simian sarcoma virus-transformed cells. Proc. Natl. Acad. Sci. USA. 84:2317-2321.

43. Zeder-Lutz, G., D. Altschuh, H. Geyser, E. Trifilieff, G. Sommermeyer, and M. Regenmortel. 1993. Monoclonal antipeptide antibodies: affinity and kinetic rate constants measured for the peptide and the cognate protein using a biosensor technology. Mol. Immunol. 30:145-155.

44. Brijham-Burke, M., J. R. Edwards, and D. J. O’Shannessy. 1992. Detection of receptor-ligand interactions using surface plasmon resonance: model studies employing the HIV-1gp 120/CDH interaction. Anal. Biochem. 205:125-131.

45. Hermiston, M. L., C. G. Latham, J. I. Gordon, and K. A. Roth. 1992 Simultaneous localization of six antigens in single sections of transgenic mouse intestine using a combination of light and fluorescence microscopy. J. Histochem. Cytochem. 40:1283-1290.

46. Rönnstrand, L., L. Terracio, L. Claesson-Welsh, C.-H. Heldin, and K. Rubin. 1988. Characterization of two monoclonal antibodies against the externa domain of the receptor for platelet-derived growth factor. J. Biol. Chem. 263:10429-10435.

47. Ansel, J. C. J. P. Tiesman, J. E. Olerud, J. G. Krueger, J. F. Krane, D. C. Tara, G. D. Shipley, D. Gilbertson, M. L. Usui, and C. E. Hart. 1993. Huma keratinocytes are a major source of cutaneous platelet-derived growth factor. $J$. Clin. Invest. 92:671-678.

48. Ross, R., J. Masuda, E. W. Raines, A. M. Gown, S. Katsuda, M. Sasahara L. T. Malden, H. Masuko, and H. Sato. 1990. Localization of PDGF-B protein in macrophages in all phases of atherogenesis. Science (Wash. DC). 248:10091012.

49. Cooper, D. M., Y. Z. Yu, P. Hennessey, F. Ko, and M. C. Robson. 1994 Determination of endogenous cytokines in chronic wounds. Ann. Surg. 219:688692.

50. Raines, E. W., and R. Ross. 1992. Compartmentalization of PDGF on extracellular binding sites dependent on exon-6-encoded sequences. J. Cell Biol. 116:533-543.

51. Khachigian, L. M., and C. N. Chesterman. 1992. Platelet-derived growth factor and alternative splicing: a review. Pathology. 24:280-290.

52. Bywater, M. F. Rorsman, E. Bongcam-Rudloff, G. Mark, A. Hammacher, C. H. Heldin, B. Westermark, and C. Betsholtz. 1988. Expression of recombinant platelet-derived growth factor A- and B-chain homodimers in rat-1 cells and human fibroblasts reveals differences in protein processing and autocrine effects. Mol. Cell. Biol. 8:2753-2762.

53. Nakahara, K., H. Nishimura, M. Kuro-o, S. Takewaki, M. Iwas, A. Ohkubo, Y. Yazaki, and R. Nagai. 1992. Identification of three types of PDGF-A chain gene transcripts in rabbit vascular smooth muscle and their regulated expression during development and by angiotensin II. Biochem. Biophys. Res. Commun. 184:811-818.

54. Sánchez, A., C. Chesterman, and M. J. Sleigh. 1991. Novel PDGF-A gene transcripts derived by alternative mRNA splicing. Gene (Amst.). 98:295-298.

55. Young, R. M., A. E. Mendoza, T. Collins, and S. H. Orkin. 1990. Alternatively spliced platelet-derived growth factor A-chain transcripts are not tumor specific but encode normal cellular proteins. Mol. Cell. Biol. 10:6051-6054.

6. Nister, M., A. Hammacher, K. Mellstrom, A. Siegbahn, L. Ronnstrand, B. Westermark, and C. H. Heldin. 1988. A glioma-derived PDGF-A chain homodimer has different functional activities from a PDGF-AB heterodimer purified from human platelets. Cell. 52:791-799.

77. Shure, D., R. M. Senior, G. L. Griffin, and T. F. Deuel. 1992. PDGF-AA homodimers are potent chemoattractants for fibroblasts and neutrophils, and for monocytes activated by lymphocytes or cytokines. Biochem. Biophys. Res. Commun. 186:1510-1514.

58. Montgomery, E. A., J. M. Meis, M. S. Mitchell, and F. M. Enzinger. 1992. Atypical decubital fibroplasia. A distinctive fibroblastic pseudotumor occurring in debilitated patients. Am. J. Surg. Pathol. 16:708-715. 